\title{
Serial immunoreactive erythropoietin levels in autologous blood donors
}

\author{
A. Lorentz, A. Jendrissek, K.U. Eckardt, M. Schipplick, P.M. Osswald, and A. Kurtz
}

\begin{abstract}
The variations in plasma erythropoietin (EPO) concentration during preoperative deposit of autologous blood were studied in 12 patients ( 8 men, 4 women). Four donations were scheduled at weekly intervals. A predonation hemoglobin concentration of $11 \mathrm{~g}$ per $\mathrm{dL}(110 \mathrm{~g} / \mathrm{L})$ was required. Hemoglobin concentration decreased from $14.3 \pm 1.1 \mathrm{~g}$ per $\mathrm{dL}(143 \pm 11 \mathrm{~g} / \mathrm{L})$ (mean $\pm \mathrm{SD}$ ) before the first donation to 11.7 $\pm 0.7 \mathrm{~g}$ per dL $(117 \pm 7 \mathrm{~g} / \mathrm{L})$ on Day $22(p \leq 0.0001)$. Reticulocyte counts increased from a median of 31,800 (range, $4900-95,000$ ) per $\mu \mathrm{L}$ (median, $32 \times 10^{9} / \mathrm{L}$ [range, $5-95 \times 10^{9} / \mathrm{L}$ ) to $93,800(16,800-194,900)$ per $\mu \mathrm{L}$ (median, $94 \times 10^{9} / \mathrm{L}$ [range, 17 $\left.\left.195 \times 10^{9} / \mathrm{L}\right]\right)$ on Day 28 ( $\left.\mathrm{p} \leq 0.01\right)$. Plasma EPO concentration was $17.8 \pm 5.1 \mathrm{mU}$ per $\mathrm{mL}$ prior to the first donation and displayed a small and transient peak after each donation. A sustained elevation followed each peak. Although plasma EPO concentration differed significantly from the baseline value after the first donation, only the peak concentrations after the second $(35.5 \pm 15.5 \mathrm{mU} / \mathrm{mL})$, third $(38.0 \pm 14.5 \mathrm{mU}$ i $\mathrm{mL})$, and fourth $(36.1 \pm 11.0 \mathrm{mU} / \mathrm{mL})$ donations exceeded the normal range. The moderate, biphasic increase in plasma EPO concentration and the moderate increase in erythropoiesis suggest two strategies in autologous blood donation that should be investigated with respect to efficiency and safety: 1) more aggressive donation schemes, which reduce donation intervals and/or the minimum hemoglobin concentration and 2) the administration of recombinant human EPO. TRANSFUSION 1991;31:650654.
\end{abstract}

Abbreviations: EPO = erythropoietin.

THE IMMUNOLOGIC AND INFECTIOUS risks of transfusion $^{1,2}$ can be minimized by the use of autologous blood. Preoperative autologous blood donation considerably reduces homologous transfusion requirements in surgery. ${ }^{3-8}$ Frozen storage of red cells allows the preoperative deposit of a large number of blood units, but it is costly and time-consuming. On the other hand, liquid storage is limited to 5 weeks for whole blood and 7 weeks for packed red cells. ${ }^{9,10}$ The efficiency of preoperative deposit in the liquid state thus depends on the rate of recovery from blood loss, that is, on the degree of stimulation of erythropoiesis.

Erythropoietin (EPO) is the primary humoral regulator of erythropoiesis. ${ }^{11}$ Increasing the availability of EPO may therefore enhance the efficiency of preoperative donation programs. This increased availability of EPO may be achieved by allowing the modulation of donation schemes (shorter donation intervals, lower minimum

From the Institute for Anesthesiology, Mannheim Clinic, Medical Faculty of the University of Heidelberg, Mannheim, Germany, and the Physiology Institute of the University of Zürich, Zurich, Switzerland.

Supported in part by a fellowship from the Deutsche Forschungsgemeinschaft, Bad Godesberg, Germany (KUE), and by Boehringer Mannheim GmbH, Mannheim, Germany.

Received for publication July 3, 1989; revision received January 7, 1991, and accepted Fcbruary 6, 1991. predonation hematocrits) to enhance endogenous EPO formation. Alternatively, recombinant human EPO may be administered, a treatment that is effective in the management of the anemia that occurs with renal failure and has recently been shown to allow the withdrawal of larger amounts of blood from animals who are phlebotomized repeatedly ${ }^{12}$ and from autologous blood donors. ${ }^{13}$

To obtain a rational basis for such preoperative donation strategies, knowledge of the pattern of variations in endogenous EPO concentration following repeated phlebotomy would be helpful. A recent study ${ }^{14}$ suggested only slight increases during preoperative deposit. However, in that study, EPO values were determined only before each donation, and thus transient increases may have been missed. In our investigation, we measured plasma EPO concentration both before and after repeated phlebotomy for autologous blood donation.

\section{Materials and Methods}

\section{Patients}

With their informed consent, we studied 12 consecutive patients scheduled for hip arthroplasty or revision hip arthroplasty and participating in the preoperative autologous blood deposit program. Anemia, coronary heart disease, congestive heart failure, uncontrolled hypertension, severe obstructive or restrictive pulmonary disease, infectious disease, cerebral sclerosis, and syncope were considered exclusion criteria for 
preoperative blood deposit. In addition, we excluded from the study patients with malignant disease and those with a serum creatinine level $>1.3 \mathrm{mg}$ per $\mathrm{dL}(100 \mu \mathrm{mol} / \mathrm{L})$.

Of the patients studied, 8 were men, and 4 were women. Their mean age was $58.0 \pm 10.5( \pm \mathrm{SD})$, and the range was 39 to 75 years. Their mean height was $167.3 \pm 9.6 \mathrm{~cm}$ ( \pm SD), with a range of 150 to $190 \mathrm{~cm}$. Their mean weight was $70.1 \pm 15.4 \mathrm{~kg}$ ( $\pm \mathrm{SD})$, with a range of 46 to $110 \mathrm{~kg}$.

\section{Blood donation}

The aim of the program was to obtain four donations of 450 $\mathrm{mL}$ of blood at weekly intervals. A patient was deferred for 1 week if the hemoglobin concentration prior to donation fell below $11 \mathrm{~g}$ per $\mathrm{dL}(110 \mathrm{~g} / \mathrm{L})$. $\mathrm{Fe}(-\mathrm{II})$-aspartate tetrahydrate (Spartocine, UBC Chemie, Kerpen, Germany), $350 \mathrm{mg}$, was prescribed three times daily, a dose that corresponds to three doses of $50 \mathrm{mg}$ of $\mathrm{Fe}^{2+}$.

Blood samples for blood cell counts, hemoglobin, and EPO determination were obtained before each donation and on the first, third, and fifth days thereafter. Serum iron and serum ferritin concentrations were determined at weekly intervals. The blood samples taken totalled $25 \mathrm{~mL}$ during the week after each donation appointment.

\section{Determination of erythropoietin}

We determined the EPO concentration in EDTA-plasma samples by radioimmunoassay as described previously, ${ }^{15}$ using a rabbit antiserum derived against recombinant human EPO, iodinated recombinant human EPO (Amersham Laboratories, Amersham, UK) as a tracer and using the 2nd International Reference Preparation for EPO (WHO/International Laboratory for Biological Standards, London, UK) as a standard. The interassay coefficient of variation is 7 percent. The geometric mean EPO level for healthy adults is $17.9 \mathrm{mU}$ per $\mathrm{mL}$, and the 5 to 95 percentile is 11 to $31 \mathrm{mU}$ per $\mathrm{mL}(\mathrm{n}=84)$.

\section{Blood cell count}

Hemoglobin concentration, red cell count, mean corpuscular volume, and white cell and platelet counts were determined by automated routine laboratory technique. Reticulocytes were counted manually.

\section{Determination of serum ferritin and serum iron}

Serum iron concentration was determined photometrically. ${ }^{16}$ Serum ferritin concentration was determined by immunofluorescence assay (normal range: men, 35-490 $\mu \mathrm{g} / \mathrm{L}$; women, 25 $380 \mu \mathrm{g} / \mathrm{L}){ }^{17}$

\section{Calculated values} (1b). ${ }^{18}$

Blood volume was estimated according to equations (1a) and

$$
\begin{aligned}
& \mathrm{PBV}=0.0236 \times \mathrm{H}^{0.725} \times \mathrm{W}^{0.425}-1.229 \quad(\text { men }) \\
& \mathrm{PBV}=0.0248 \times \mathrm{H}^{0.725} \times \mathrm{W}^{0.425}-1.954 \text { (women) }
\end{aligned}
$$

where $\mathrm{PBV}=$ predicted blood volume, $\mathrm{H}=$ height $(\mathrm{cm})$, and $\mathrm{W}=$ weight $(\mathrm{kg})$.

Red cell volume was estimated according to equation (2). ${ }^{19}$

$$
\mathrm{EV}=\mathrm{PBV} \times \mathrm{Hct} \times 0.896
$$

where $\mathrm{EV}=$ red cell volume and $\mathrm{Hct}=$ hematocrit (venous).

The recovery from red cell loss between donations, given that the hematocrit of the donated blood corresponded to that before donation and that the blood volume of each patient prior to donation did not change in the course of preoperative deposit, ${ }^{20}$ was estimated according to equation (3).

$$
\begin{aligned}
& \mathrm{ER}_{\mathrm{n} / \mathrm{n}+1}=\mathrm{EV}_{\mathrm{n}}-\left(\mathrm{EV}_{\mathrm{n}+1}\right. \\
& \left.+\mathrm{DV}_{\mathrm{n}} \times \mathrm{Hct}_{\mathrm{n}} \times 0.985\right)
\end{aligned}
$$

where $\mathrm{ER}_{\mathrm{n} / \mathrm{n}+1}=$ recovery from red cell loss between the $n$th and $(n+1)$ th donations, $\mathrm{EV}_{\mathrm{n}}$ and $\mathrm{EV}=$ red cell volume at the $n$th and $(n+1)$ th donations, $\mathrm{DV}_{\mathrm{n}}=$ the volume donated at the nth donation, and $\mathrm{Hct}_{\mathrm{n}}=$ (venous) Hct before the nth donation.

\section{Statistics}

The data were analyzed via statistical software. ${ }^{21}$ Sample distribution was tested for normality as described by ShapiroWilk. ${ }^{22}$ Samples were compared by the paired $t$ test or the Wilcoxon signed-rank test, as appropriate. The significance level was set at 5 percent.

\section{Results}

The mean calculated blood volume in these 12 patients was $4550 \pm 904 \mathrm{~mL}( \pm \mathrm{SD})$, and the range was 2819 to 6580 $\mathrm{mL}$. The mean red cell volume before the first donation was $1646 \pm 446 \mathrm{~mL}$ ( $\pm \mathrm{SD}$ ), and the range was 809 to $2519 \mathrm{~mL}$. At the first and second appointments, all 12 patients donated 1 unit of blood; at the third appointment, 10 patients donated blood, and at the fourth appointment, 8 patients did so. A total of 4 units was preoperatively deposited by each of 8 patients, as was a total of 3 units by each of 2 patients and 2 units by each of another 2 patients.

The pattern of variation in the hemoglobin concentration is shown in Fig. 1. Repeated phlebotomies led to a gradual decrease in hemoglobin concentration from $14.3 \mathrm{~g}$ per dL (143 $\mathrm{g} / \mathrm{L})$ (mean) to $13.2,12.6,11.9$, and $11.7 \mathrm{~g}$ per dL $(132,126$, 119 , and $117 \mathrm{~g} / \mathrm{L}$ ) (mean). Recovery from red cell loss by increased erythropoiesis can be estimated as $70 \mathrm{~mL}$ of red cells during the week after the first donation and $98 \mathrm{~mL}$ during the week following the fourth donation appointment. Reticulocyte count increased from a median of 31,800 (median, $32 \times 10^{9} /$

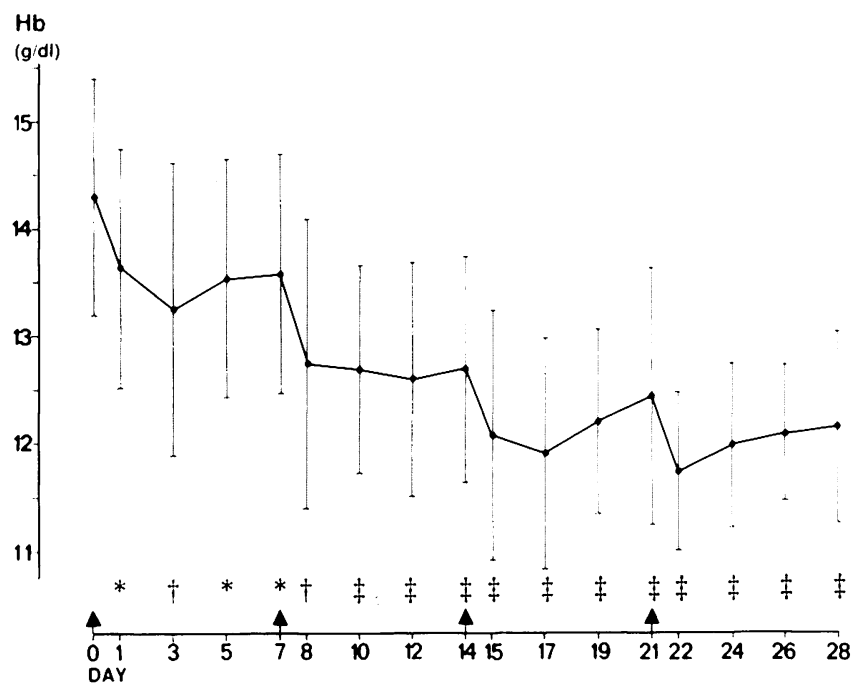

FIG. 1. Hemoglobin concentration during autologous deposit $(\mathrm{n}=$ 12). Values are presented as mean \pm SD. $\uparrow$ indicates donation appointments; number of patients donating 1 unit of blood: Day 0,12 ; Day 7, 12; Day 14, 10; Day 21, 8. ${ }^{*} p \leq 0.01, \dagger p \leq 0.001, \neq p \leq 0.0001$ vs. baseline value. 


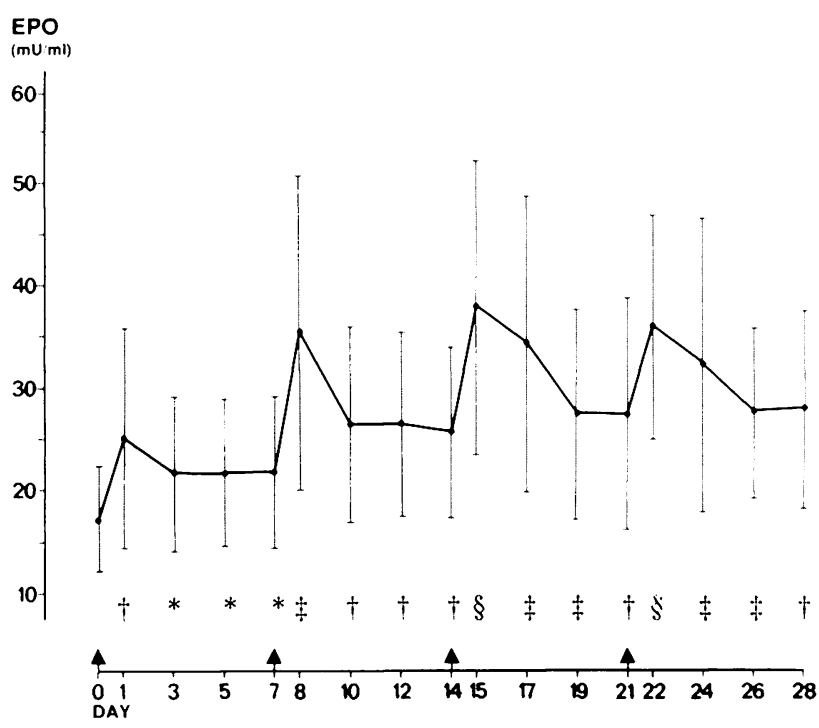

FIG. 2. Plasma immunorcactive EPO concentration during autologous deposit $(n=12)$. Values are represented as mean $\pm \mathrm{SD} ; 5$ to 95 percentile of healthy adults $(11-31 \mathrm{mU} / \mathrm{mL}) . \uparrow$ indicates donation appointments; number of patients donating 1 unit of blood: Day 0 , 12; Day 7, 12; Day 14, 10; Day 21, 8. ${ }^{*} p \leq 0.05, \dagger p \leq 0.01, \neq p \leq 0.001$, and $\S \mathrm{p} \leq 0.0001$ vs. baseline value.

L) (range, 4900-95,000) per $\mu \mathrm{L}$ (range, 5-95 $\times 10^{9} / \mathrm{L}$ ) before the first donation to a median of $93,800\left(94 \times 10^{9} / \mathrm{L}\right)$ (range, $16,800-194,900)$ per $\mu \mathrm{L}\left(17-195 \times 10^{9} / \mathrm{L}\right)$ on Day $28(\mathrm{p} \leq 0.01)$. Platelet and white cell counts did not change significantly.

Plasma EPO concentration before the first blood donation amounted to $17.8 \pm 5.1 \mathrm{mU}$ per $\mathrm{mL}$ (mean $\pm \mathrm{SD}$ ). As shown in Fig. 2, plasma EPO concentration displayed a small, transient peak after the first donation, a more pronounced peak after the second donation, and a longer-lasting peak after the third and fourth donations. A sustained elevation followed each peak. Although plasma EPO concentration was significantly elevated after the first donation, only those peak concentrations following the second, third, and fourth donations exceeded the normal range.

Of the variables associated with iron metabolism, serum iron concentration decreased significantly from $17.2 \pm 5.6 \mu \mathrm{mol}$ per $\mathrm{L}$ (mean $\pm \mathrm{SD}$ ) before deposit to $10.5 \pm 3.4 \mu \mathrm{mol}$ per L on Day 28 ( $\mathrm{p} \leq 0.01)$. Serum ferritin concentration decreased significantly from a median of 170 (range, 40-400) $\mu \mathrm{g}$ per L to 50 (range, 20-210) $\mu \mathrm{g}$ per $\mathrm{L}(\mathrm{p} \leq 0.01)$. Mean corpuscular volume $\left(88 \pm 4 \mu \mathrm{m}^{3}[88 \pm 4 \mathrm{fL}\right.$ ] prior to donation vs. $89 \pm$ $5 \mu \mathrm{m}^{3}$ [89 $\pm 5 \mathrm{fL}$ ] on Day 28), and mean corpuscular hemoglobin $(31 \pm 2$ pg vs. $32 \pm 2$ pg) did not change significantly during the time of investigation.

\section{Discussion}

After blood donation, blood volume is restored within 48 to 72 hours. ${ }^{23-25}$ The gradual fall of the hemoglobin concentration after each donation in our study complies with these results. Recovery from red cell loss, however, is slow in patients who exhibit the range of hemoglobin concentrations usually required for autologous donations $(\geq 11 \mathrm{~g} / \mathrm{dL}[\geq 110 \mathrm{~g} / \mathrm{L}]) .{ }^{26,27}$ This limits their ability to make preoperative blood deposits, if liquid storage is used. Donations are usually scheduled in weekly intervals. ${ }^{28,29}$ If this donation scheme were used for patients from whom 3 blood units were requested, 12 percent of the male patients and 35 percent of the females would have been deferred at least once in a previous study. ${ }^{4}$ The average number of preoperatively deposited units per patient was $2.8,{ }^{4}$ whereas other preoperative donation programs have obtained only 2.2 units. ${ }^{30}$

The rate of recovery from red cell loss depends on the degree of stimulation of erythropoiesis, of which EPO is considered to be the main regulator. ${ }^{11}$ Our results in the patients studied show that acute reduction of the blood volume by $450 \mathrm{~mL}$ caused a biphasic increase of plasma EPO levels. A peak concentration was measured 24 hours after donation, which preceded the lowest hemoglobin concentration. The EPO concentration then showed a plateau at lower, but still elevated levels from Day 3 to Day 7 after the first and second donations and from Day 5 to Day 7 after the third and fourth donations. A recent study in patients preoperatively donating autologous blood also found only a small rise in serum EPO concentration following phlebotomy. The serum EPO concentration was significantly different from the baseline value in female donors before the second donation and in male donors before the third donation. No serial measurements were performed. ${ }^{14}$

A biphasic increase of EPO levels has also been observed in $\operatorname{man}^{31-33}$ and rodents ${ }^{31,34,35}$ upon exposure to continuous normobaric or hypobaric hypoxia. The reason for the early decline, which occurs before red cell volume increases, is not known. It appears not to be due to a short loop feedback control mechanism of EPO secretion through direct inhibition or via its target cells. ${ }^{36}$ It may result from an adaptation to hypoxia at EPO's cellular production sites or from compensatory mechanisms that increase oxygen availability, such as an increase in cardiac output or a decrease in oxygen affinity of hemoglobin. ${ }^{37,38}$

Irrespective of the cause of the specific temporal pattern of EPO concentration associated with phlebotomy, the observation that EPO levels and therefore EPO production respond to slight changes in oxygen availability is physiologically important. This finding supports the concept that the normal plasma EPO levels in healthy persons are the result of oxygen-dependent EPO production. However, the change in EPO production in relation to changes in the hemoglobin concentration is not constant throughout the range of hemoglobin concentrations. In this study, we found a sustained increase in plasma EPO of $10.2 \mathrm{mU}$ per $\mathrm{mL}$ upon lowering the normal hemoglobin concentration by $2.1 \mathrm{~g}$ per dL $(21$ $\mathrm{g} / \mathrm{L})$. The same absolute reduction of hemoglobin, starting from values $<10 \mathrm{~g}$ per $\mathrm{dL}(<100 \mathrm{~g} / \mathrm{L})$, would increase EPO levels by $100 \mathrm{mU}$ per $\mathrm{mL}$ and more. ${ }^{39}$ Thus, the sensitivity of EPO secretion to changes in the hemo- 
globin concentration appears rather low, in the range of low-normal to slightly subnormal hemoglobin values.

The rate of erythropoiesis can be increased to twice normal or more if the hematocrit is lowered to 32 to 37 percent $(0.32-0.37) .{ }^{40} \mathrm{~A}$ total of $500 \mathrm{~mL}$ of blood can be donated in weekly intervals if iron is given orally in high dosage. After repeated donations, the hematocrit stabilizes near 30 percent $(0.30) .{ }^{25}$ In our patients, we found a drop in the hemoglobin concentration of 15 percent 1 week after the fourth donation. The decline in hemoglobin concentration was associated with an increased erythropoiesis, as reflected by the elevation in reticulocyte counts and the estimated recovery from red cell loss. Whereas reticulocytosis represents both increased erythropoiesis and premature release of red cells from the bone marrow, ${ }^{41}$ the estimated recovery of red cell volume indicates a stimulation of erythropoiesis to twice the normal rate.

The oral iron supplementation prescribed constitutes a compromise between desirable dosage and low patient compliance resulting from gastrointestinal side effects. ${ }^{6,42}$ The drop in serum iron and serum ferritin concentrations shows that iron absorption cannot cope with increased demand. The serum ferritin concentrations measured, however, are usually not associated with depleted iron stores. ${ }^{43}$ It has also been demonstrated that, within the range of hemoglobin concentrations attained in the present study, sufficient iron for erythropoiesis can be supplied either from full iron stores or-in patients with little or no storage iron-from high-dose oral iron medication alone. ${ }^{40}$ Thus, iron availability was probably not the factor that limited erythropoiesis.

In the absence of iron deficiency, erythropoiesis is mainly determined by the availability of EPO. ${ }^{11}$ As the increase in EPO concentration and the stimulation of erythropoiesis are only moderate following repeated phlebotomy, different strategies may be adopted to increase EPO levels and erythropoiesis.

1. The application of exogenous recombinant human EPO has been shown to accelerate the recovery of red cell volume in phlebotomized animals ${ }^{12}$ as well as in autologous blood donors. ${ }^{13}$ Its use in healthy persons, however, is still hampered by the facts that not all side effects of the recombinant hormone may yet be known and that the reported side effects ${ }^{44,45}$ are not completely understood in regard to their causal mechanisms. If these concerns are overcome with increased experience in the treatment of chronic anemia with recombinant human $\mathrm{EPO}$, its use may acquire a place in preoperative autologous blood donation.

2. It is tempting to speculate that modified donation schemes may result in more efficient stimulation of erythropoiesis. Reducing the time between donations, to 3 days, for example, may lead to the occurrence of EPO peak concentrations at shorter intervals. In view of the exponential inverse relationship between EPO levels and hematocrit, a reduction in the minimum predonation hematocrit could lead to a more significant increase in EPO concentrations. Whether such donation schemes do indeed increase EPO levels and erythropoiesis during autologous blood donation and decrease perioperative homologous blood requirements, and whether a lower minimum predonation hematocrit is acceptable in certain groups of patients remain to be investigated.

\section{Acknowledgments}

The technical assistance of U. Vogel is gratefully acknowledged. Serum iron and serum ferritin determinations were carried out by Dr. P. Haux, Institut für Klinische Chemie, Universitätsklinikum Mannheim.

\section{References}

1. George CD, Morello PJ. Immunologic effects of blood transfusion upon renal transplantation, tumor operations, and bacterial infections. Am J Surg 1986;152:329-37.

2. Mollison PL, Engelfriet CP, Contreras M. Blood transfusion in clinical medicine. 8th ed. Oxford: Blackwell, 1987.

3. Bailey TE Jr, Mahoney OM. The use of banked autologous blood in patients undergoing surgery for spinal deformity. J Bone Joint Surg [Am] 1987;69:329-32.

4. Lorentz A, Schipplick M, Gmehlin U, Osswald PM, Winter M. [Preoperative autologous blood deposit and liquid storage for replacement arthroplasty] (Eng abstract). Anaesthesist 1989;38:480-9.

5. Marmor L, Berkus D, Robertson JD, Wilson MT, Meeske KA. Banked autologous blood in total hip replacement. Surg Gynecol Obstet 1977;145:63-4.

6. Swanson DA, Lo RK, Lichtinger B. Predeposit autologous blood transfusions in patients undergoing irradiation and radical cystectomy. J Urol 1983;130:892-4.

7. Thomson JD, Callaghan JJ, Savory CG, Stanton RP, Picrce RN. Prior deposition of autologous blood in elective orthopaedic surgery. J Bone Joint Surg [Am] 1987;69:320-4

8. Woolson ST, Marsh JS, Tanner JB. Transfusion of previously deposited autologous blood for patients undergoing hip-replacement surgery. J Bone Joint Surg [Am] 1987;69:325-8.

9. Moore GL, Peck CC, Sohmer PR, Zuck TF. Some properties of blood stored in anticoagulant CPDA-1 solution: a brief summary. Transfusion 1981;21:135-7.

10. Walker WH, Handel KD, Netz M, Gänshirt KH. [49-day storage of erythrocyte concentrates in PAGGS-sorbitol]. Beitr Infusionsther Klin Ernähr 1986;18:157-7.

11. Spivak JL. The mechanism of action of erythropoietin. Int J Cell Cloning 1986;4:139-66.

12. Levine EA, Rosen AL, Gould SA, et al. Recombinant human erythropoietin and autologous blood donation. Surgery 1988;104:365-9.

13. Goodnough LT, Rudnick S, Price TH, et al. Increased preoperative collection of autologous blood with recombinant human erythropoietin therapy. N Engl J Med 1989;321:1163-8.

14. Kickler MS, Spivak JL. Effect of repeated whole blood donations on serum immunoreactive erythropoietin levels in autologous donors. JAMA 1988;260:65-7.

15. Eckardt KU, Kurtz A, Hirth P, Scigalla P, Wieczorek L, Bauer $\mathrm{CH}$. Evaluation of the stability of human erythropoietin in samples for radioimmunoassay. Klin Wochenschr 1988;66:241-5.

16. Siedel J, Wahlefeld AW, Ziegenhorn J. Improved ferrozine ${ }^{R}$-based reagent for the determination of serum iron (transferrin iron) without deproteinization (abstract). Clin Chem 1984;30:975.

17. Hemmilä I, Dakubu S, Mukkala VM, Siitari H, Lövgren T. Europium as a label in time-resolved immunofluorometric assays. Anal Biochem 1984;137:335-43.

18. Nadler SB, Hidalgo JU, Bloch T. Prediction of blood volume in normal human adults. Surgery 1962;51:224-32. 
19. Najean $Y$, Deschrywer F. The body/venous haematocrit ratio and its use for calculating total blood volume from fractional volumes. Eur J Nucl Med 1984;9:558-60.

20. Gabutti V, Piga A, Fortina P, Miniero R, Nicola P. Correlation between transfusion requirement, blood volume and haemoglobin level in homozygous $\beta$-thalassaemia. Acta Hacmatol (Basel) 1980;64:103-8

21. SAS user's guide. Basics. Cary, NC: SAS Institute, Inc., 1985.

22. Shapiro SS, Wilk MB. An analysis of variance test for normality (complete samples). Biometrica 1965;52:591-611.

23. Adamson J, Hillman RS. Blood volume and plasma protein replacement following acute blood loss in normal man. JAMA 1968;205:609-12.

24. Moore FD. The effects of hemorrhage on body composition. $\mathrm{N}$ Engl J Med 1965;273:567-77.

25. Wadsworth GR. Recovery from acute haemorrhage in normal men and women. J Physiol (Lond) 1955;129:583-93.

26. Coleman DH, Stevens AR, Dodge HT, Finch CA. Rate of blood regeneration after blood loss. Arch Intern Med 1953;92:341-9.

27. Schmidt PJ, ed. Standards for blood banks and transfusion services. 11th ed. Arlington: American Association of Blood Banks, 1984.

28. Autologous blood transfusions. Council on Scientific Affairs. JAMA $1986 ; 256: 2378-80$.

29. Gilcher RO, Belcher L. Predeposit programs. In: Sandler SG, Silvergleid AJ, eds. Autologous transfusion. Arlington: American Association of Blood Banks, 1983:11-22.

30. Toy PT, Strauss RG, Stehling CC, et al. Predeposited autologous blood for elective surgery. A national multicenter study. N Engl J Med 1987;316:517-20.

31. Abbrecht PH, Littell JK. Plasma erythropoietin in men and mice during acclimatization to different altitudes. J Appl Physiol 1972;32:54-8.

32. Faura J, Ramos J, Reynafarje C, English E, Finne P, Finch CA. Effect of altitude on erythropoiesis. Blood 1969;33:668-76.

33. Milledge JS, Cotes PM. Serum crythropoietin in humans at high altitude and its relation to plasma renin. J Appl Physiol 1985;59:360-4

34. Fried W, Johnson C, Heller P. Observations on regulation of erythropoiesis during prolonged periods of hypoxia. Blood 1970;36:607-16.

35. Jelkmann W. Temporal pattern of erythropoietin titers in kidney tissue during hypoxic hypoxia. Pflügers Arch 1982;393:88-91.

36. Eckardt KU, Dittmer J, Ncumann R, Bauer C, Kurtz A. Decline of erythropoietin formation at continuous hypoxia is not due to feedback inhibition. Am J Physiol 1990;258:F1432-7.
37. Martin E, Hansen E, Peter K. Acute limited normovolemic hemodilution: a method for avoiding homologous transfusion. World J Surg 1987;11:53-9.

38. Sunder-Plassmann L, Kessler M, Jesch F, Dieterle R, Messmer $\mathrm{K}$. Acute normovolemic hemodilution. Changes in tissue oxygenation and hemoglobin oxygen affinity. Bibl Haematol 1975;41:4453.

39. Erslev AJ, Wilson J, Caro J. Erythropoietin titers in anemic, nonuremic patients. J Lab Clin Med 1987;109:429-33.

40. Hillman RS, Henderson PA. Control of marrow production by the level of iron supply. J Clin Invest 1969;48:454-60.

41. Hillman RS. Characteristics of marrow production and reticulocyte maturation in normal man in response to anemia. J Clin Invest 1969;48:443-53.

42. Kaltwasser JP. Grundlagen der Transfusionsmedizin. Eisenstoffwechsel. In: Mueller-Eckhardt C, ed. Transfusionsmedizin. Berlin: Springer, 1988:109-22.

43. Bothwell TH, Charlton RW, Cook JD, Finch CA. Iron metabolism in man. Oxford: Blackwell, 1979

44. Eschbach JW, Egrie JC, Downing MR, Browne JK, Adamson JW. Correction of the anemia of end-stage renal disease with recombinant human erythropoietin. Results of a combined phase I and II clinical trial. N Engl J Med 1987;316:73-8.

45. Winearls CE, Oliver DO, Pippard MJ, Reid C, Downing MR, Coles PM. Effect of human erythropoietin derived from recombinant DNA on the anaemia of patients maintained by chronic haemodialysis. Lancet 1986;2:1175-8.

Arnulf K. Lorentz, Dr med, Resident, Institut für Anästhesiologie an der Fakultät für Klinische Medizin Mannheim der Universität Heidelberg, Theodor-Kutzer-Ufer, 6800 Mannheim, Germany. [Reprint requests]

Andreas Jendrissek, Student, Institut für Anästhesiologie.

Kai-Uwe Eckardt, Dr med, Research Fellow, Physiologisches Institut der Universität Zürich, Zurich, Switzerland.

Martin Schipplick, Dr med, Resident, Institut für Anästhesiologie.

Peter M. Osswald, Prof Dr med, Senior Resident, Institut für Anästhesiologie.

Armin Kurtz, Priv-Doz Dr med, Senior Assistant, Physiologisches Institut. 